УДК 614.777:628.16

\title{
ВИКОРИСТАННЯ ФАСОВАНОЇ ВОДИ НАСЕЛЕННЯМ МІСТА ТЕРНОПОЛЯ ЗА РЕЗУЛЬТАТАМИ АНКЕТНОГО ОПИТУВАННЯ
}

\author{
О. В. Лотоцька, К. Т. Волощинська \\ ДВНЗ «Тернопільський державний медичний університет \\ імені І. Я. Горбачевського МОЗ України»
}

\begin{abstract}
У статті проаналізовано результати соціологічного опитування та узагальнено дані незалежної оцінки особливостей вживання води населенням м. Тернополя. Встановлено, що 80,1 \% жителів не задоволені якістю водогінної води і використовують для пиття різні альтернативні джерела водопостачання: фільтровану (в 46 \%) або фасовану (у 21 \%) воду. Більшість опитаних вживає фасовану воду нерегулярно, 1-3 рази на тиждень, і використовує в основному для тамування спраги під час прогулянок, фізичного тренування, спортивних змагань. Під час купівлі фасованої води вирішальним фактором при здійсненні вибору для більшості опитаних є смакові якості води. Все це свідчить про те, що жителі м. Тернополя, вживаючи питну воду в достатній кількості, незважаючи на недостатню якість водогінної води, надають перевагу традиційним джерелам водопостачання, а саме водогонам, колодязям і каптажам.
\end{abstract}

\section{USING OF BOTTLED WATER BY THE POPULATION OF TERNOPIL ACCORDING TO THE RESULTS OF THE QUESTIONNAIRE SURVEY}

\author{
O. V. Lototska, K. T. Voloschynska
}

\section{Horbachevsky Ternopil State Medical University}

\begin{abstract}
The article analyzes the results of a sociological survey and summarizes the data of an independent assessment of the water consumption of the population of Ternopil. It was established that $80.1 \%$ of residents are not satisfied with the quality of water supply and use different alternative sources of water for drinking: filtered (in $46 \%$ ) or bottled (in $21 \%$ ) water. Most respondents use packaged water irregularly, buying it 1-3 times a week, and use it mainly to suffer thirst during walks, physical training, sports competitions. When purchasing packaged water the deciding factor in choosing the majority of respondents is the taste of water. All this testifies that residents of the city of Ternopil drink enough water, despite the insufficient quality of water supply, prefer traditional sources of water supply: piped water, wells and springs.
\end{abstract}

Вступ. Добре відомо, що життя і здоров'я без якісної води не можливе. Але в останні роки внаслідок антропогенного забруднення поверхневих і підземних вод, які $є$ джерелами питного водопостачання недостатньо очищеними стічними водами промислових та комунальних підприємств, через незадовільний санітарно-технічний стан водопровідних мереж та використання на водогонах застарілих водоочисних технологій, через відсутність санітарно-захисних зон тощо, якість водогінної води значно погіршилася [1]. Нестача доброякісної води призвела до пошуку населенням альтернативних методів водопостачання. Одним із таких методів є використання розфасованих питних вод, які населення традиційно називає «мінеральними». Але це неправильно. Адже мінеральною

() О. В. Лотоцька, К. Т. Волощинська, 2018 $\epsilon$ та вода, хімічний склад та фізичні властивості якої дозволяють застосовувати ії з лікувально-профілактичною метою. До мінеральних питних вод належать води із загальною мінералізацією не менше 2 г/л, а також води з меншою мінералізацією, якщо вони містять біологічно активні речовини у кількості, що відповідає нормам для питних мінеральних вод [2].

Фахівці вважають, що втамовувати спрагу такими водами не варто. Щоб питна вода не нашкодила, вибирати її потрібно, попередньо уважно вивчивши етикетку, оцінивши їі властивості та усвідомивши, які захворювання вона лікує. Для щоденного пиття краще обирати природні столові води, рівень мінералізації яких менше 1 г/л, які освіжають та очищають організм від шлаків, або фасовані питні води, які є перспективним напрямком альтернативного водопостачання населення [3-5]. 
Фасована питна вода в останні роки набуває популярності в усьому світі, у тому числі й в Україні. Адже це завжди вода гарантованої якості. Але кількість жителів України, які купують таку воду, - лише 6 \%. Це пов'язано з кризовою економікою і недостатністю коштів у населення. За даними Міжнародного консалтингового агентства ринку напоїв Zenith International, в Західній Європі фасованою питною водою подібної якості користуються 47 \% населення, а в США - 95 \% [6].

Основна частина. Враховуючи актуальність проблеми, ми вирішили провести соціологічне опитування та узагальнити дані незалежної оцінки скільки і яку воду споживає населення м. Тернополя. Було проведено анкетування жителів м. Тернополя за допомогою анкети, яка містила 28 запитань і була розроблена за зразком опитувальника ДУ «нститут громадського здоров'я імені О. М. Марзєєва НАМНУ». У результаті було отримано інформацію за такими напрямками: скільки і яку воду споживають, як оцінюють якість водогінної води та чи використовують інші альтернативні джерела водопостачання. На сьогодні опрацьовано 176 анкет. Більшість опитаних (73,3 \%) проживає у місті, з них 67,6 \% - жінки. 80 \% респондентів були віком до 20 років.

За результатами анкетного опитування було встановлено, що якість водогінної питної води не влаштовує 80,1 \% населення. 76,7 \% опитаних вважають, що погана якість питної води централізованих систем водопостачання пов'язана з можливими відхиленнями від гігієнічних нормативів. Найбільше не задовольняють споживачів органолептичні показники води з водогону. 47,7 \% опитаних не влаштовує запах водогінної води, 69,9 \% - смак. 39,2 \% респондентів відзначають, що вода $є$ каламутною, а 54,0 \% - що вона має колір.

Достатня кількість води потрібна людині не лише для життя, але й для здоров'я. Для дорослої людини норма вживання води, на думку більшості медиків, коливається в межах 30-40 мл води на 1 кг маси тіла, тобто, при вазі 50 кг - це 1,5-2 л води, при вазі 75 кг 2,5-3 л на добу [6]. Після проведеного анкетування ми встановили, що більша частина респондентів щодня вживає достатню кількість води: 0,5-1,5 л - 54,0 \%, 1,5-2,0 - 32,4 \% та більше 2,0 л - 10,2 \%. Лише 5,1\% опитаних випиває за день менше 0,5 л води (рис. 1).

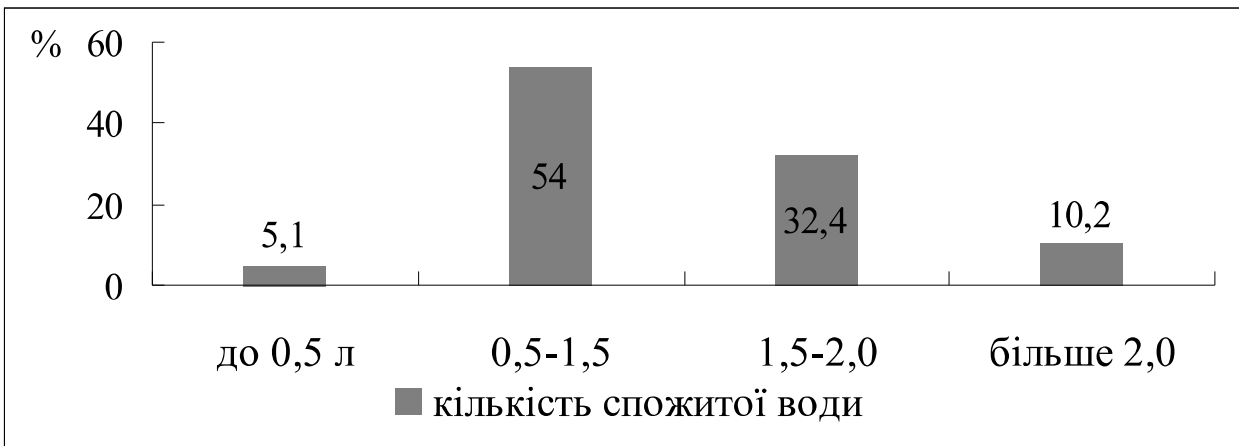

Рис. 1. Розподіл опитаних (у \%) за кількістю спожитої води на добу (за результатами анкетування).

На запитання, чи мають респонденти ознаки дефіциту води в організмі, 42,6 \% відповіли негативно, а 13,1 \% було важко визначитися. Але разом із тим, у частини опитаних є скарги, які можуть бути ознаками дефіциту води в організмі, такі як втома і (або) перепади настрою - 34,1 \%, голод, навіть незважаючи на те, що ви недавно їли - 8,5 \%, біль у спині або суглобах 9,6 \%, тьмяна, суха шкіра і (або) виражені зморшки 13,6 \%; рідке сечовипускання, темний, концентрований колір сечі і (або) закрепи - 1,1\%.

На запитання: «Чим Ви зазвичай втамовуєте спрагу?», більша частина опитаних (46 \%) відповіла, що для пиття використовує фільтровану воду, практично однакова кількість п'є воду з водогону (18\%), газовану воду (21\%) або чай (17\%), невеликий відсоток опитаних - сік (7 \%) (рис. 2).
Зараз набуло популярності вживання фасованої питної води. 3 кожним роком збільшується їі споживання. Тому ми вирішили вияснити, чи дійсно це так і на скільки поширене серед населення м. Тернополя. Кожний день їі купують для пиття 13,1 \% анкетованих і 1-3 рази на тиждень - ще 44,9\% респондентів. 27,8 \% опитаних вживають цю воду дуже мало - 1-3 рази на місяць і 14,2 \% - рідше 1 разу на місяць (рис. 3).

Більшість анкетованих - 96 осіб (55,0 \%) - вживає цю воду для тамування спраги під час прогулянок, фізичного тренування, спортивних змагань. Частина респондентів - 16 осіб (9,0 \%) - купує фасовану воду лише для урочистих подій. 30 опитаних (17,0 \%) вживає цю воду тому, що їх не задовольняє якість водопровідної води, а інших 30 - тому, що їм ця вода просто подобається. 1,1 \% респондентів вживають 
мінеральну воду за призначенням лікаря і така ж кількість - використовує для приготування їжі (рис. 4).

Під час купівлі фасованої води вирішальним фактором при здійсненні вибору для більшості опитаних, а саме 80 осіб (45,5 \%) є смакові якості води. Менша кіль- кість респондентів - 48 осіб (27,3 \%) - звертає увагу на мінеральний склад води. Ціна та популярність торгової марки мають вирішальне значення для однакової кількості респондентів - по 24 особи (13,6 \%) здійснюють вибір води згідно з цими показниками (рис. 5).

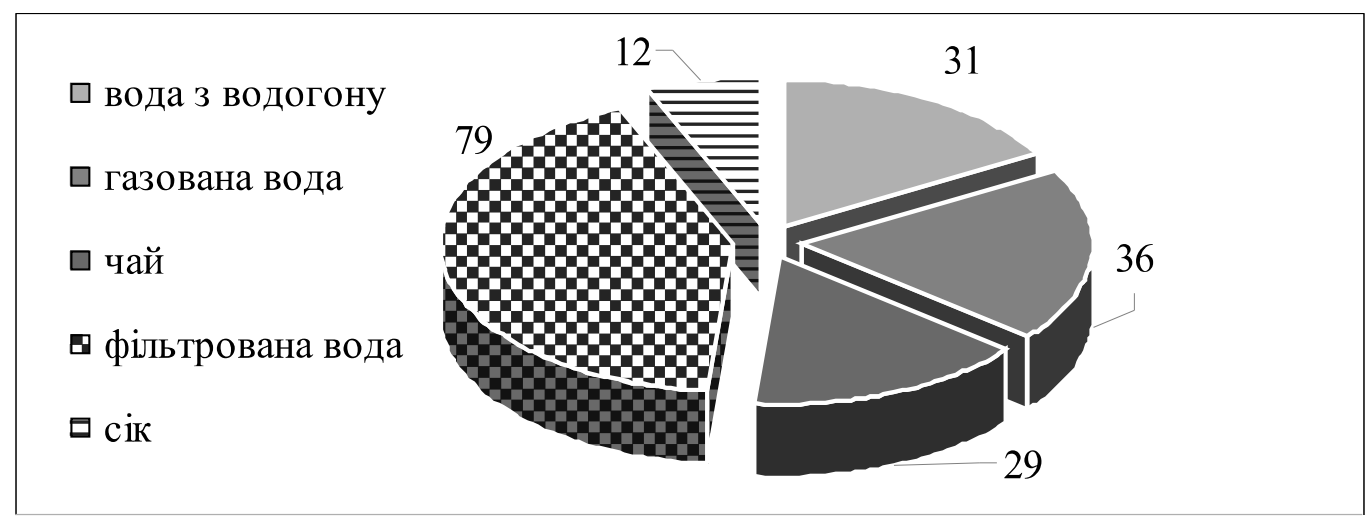

PUс. 2. Основні види джерел для тамування спраги населення м. Тернополя.

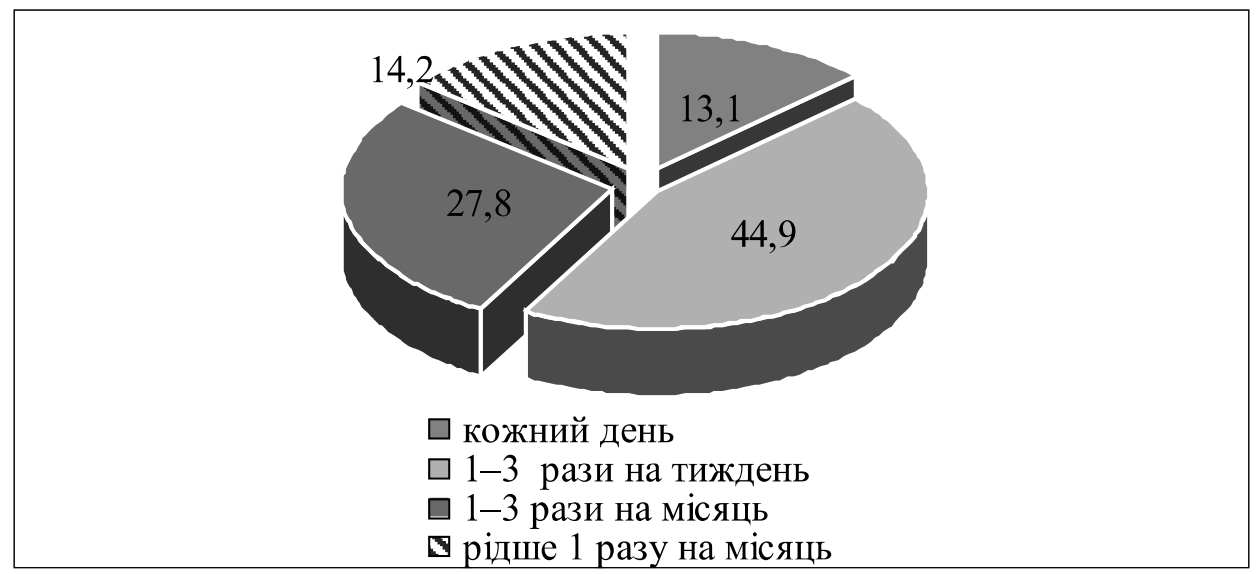

Рис. 3. Частота купування фасованої води населенням м. Тернополя.

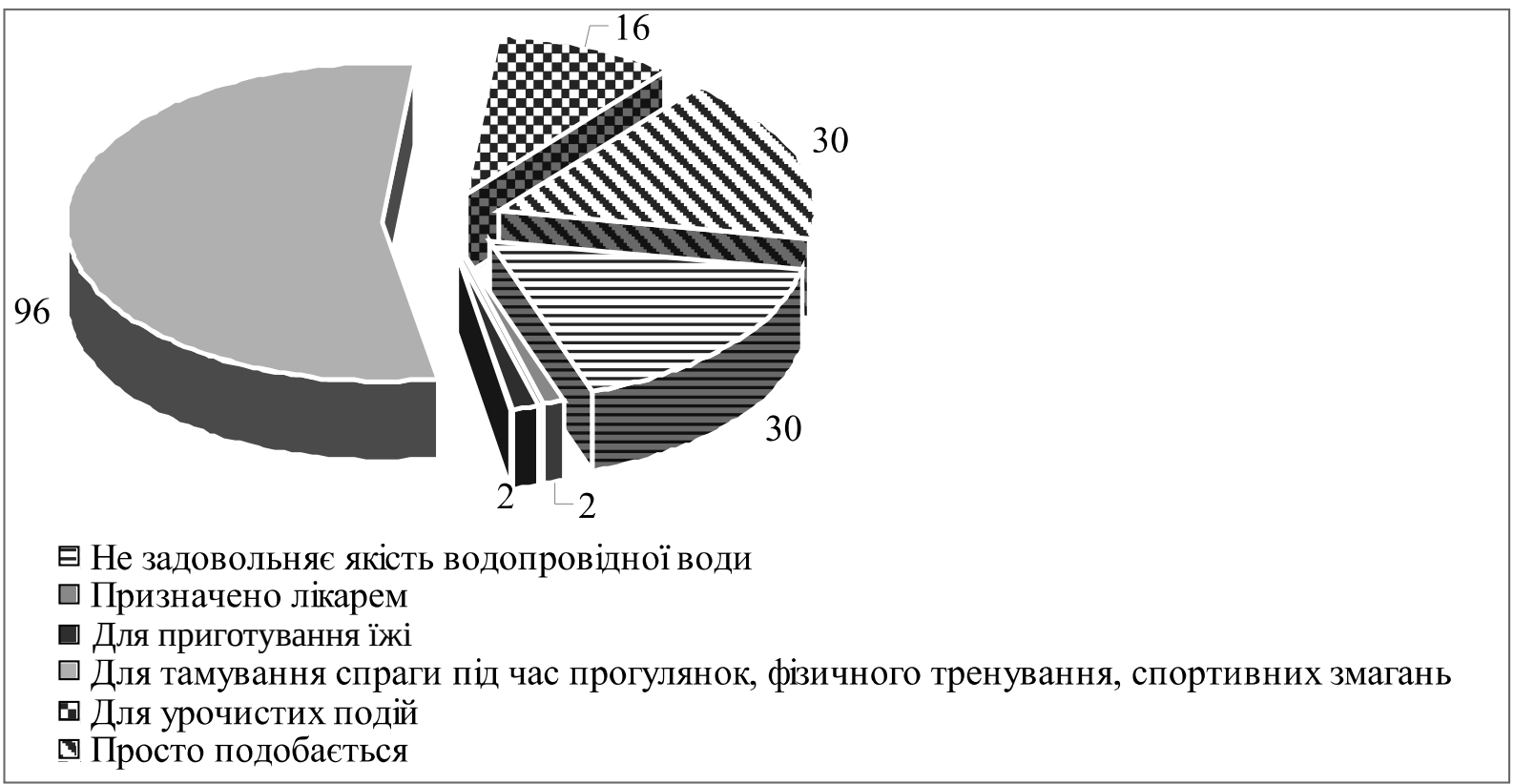

Рис. 4. Аналіз основних причин використання фасованої води респондентами. 


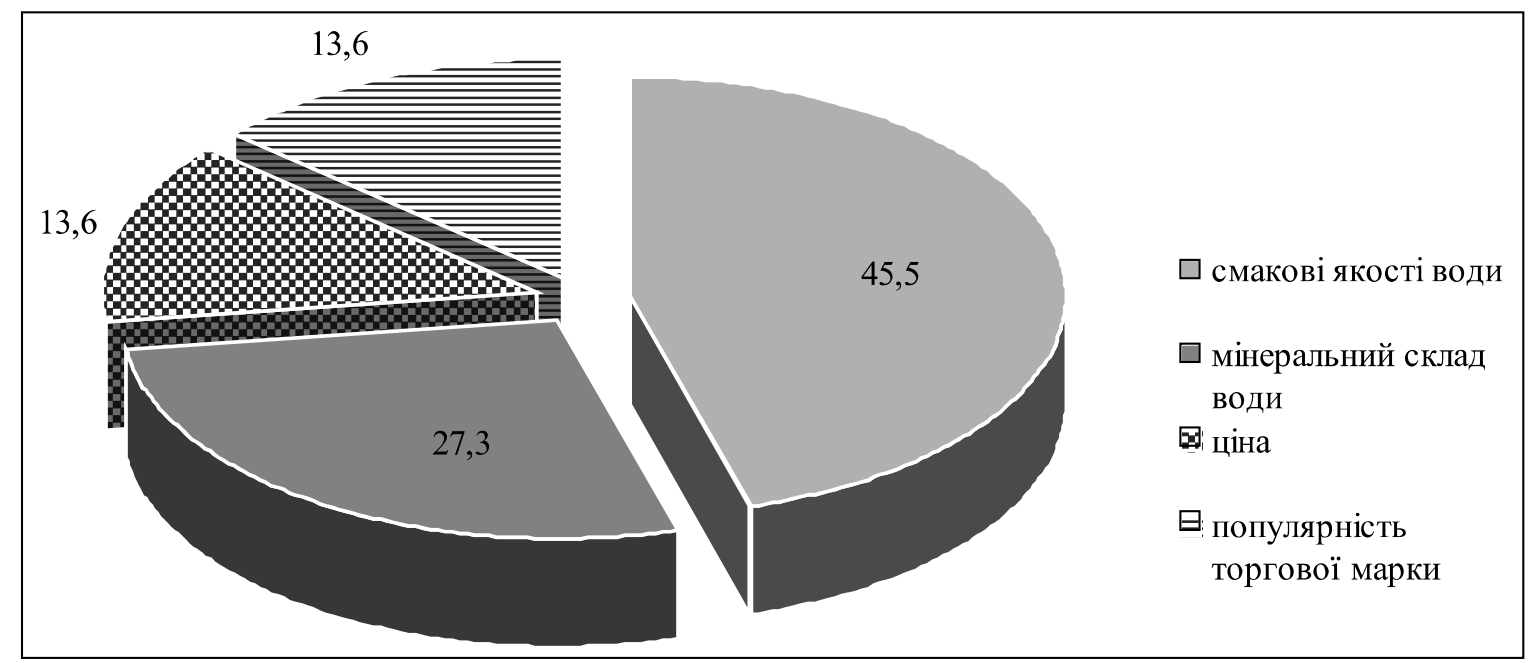

РИС. 5. Вирішальний фактор при здійсненні вибору фасованої води (у \%).

При придбанні фасованої води 47,7 \% респондентів надають перевагу негазованій, 33,5 \% - слабогазованій і 18,7 \% - сильногазованій.

Висновки. Проведені дослідження встановили, що 80,1 \% жителів м. Тернополя не задоволені якістю водогінної води і використовують для пиття різні альтернативні джерела водопостачання: фільтровану (в 46 \%) або фасовану (у $21 \%$ ) воду. Більшість опитаних вживає фасовану воду нерегулярно, 1-3 рази на тиждень, і використовує в основному для тамування

\section{СПИСОК ЛІТЕРАТУРИ}

1. Прокопов В. О. Вплив мінерального складу питної води на стан здоров'я населення (огляд літератури) // В. О. Прокопов, О. Б. Липовецька // Гігієна населених місць. - 2012. - № 59. - С. 63-73.

2. Фоменко Н. В. Рекреаційні ресурси та курортологія : навч. посіб. / Н. В. Фоменко. - К. : Центр навчальної літератури, 2007. - 312 с.

3. Мониторинг качества минеральных природных столовых вод как важная гигиеническая проблема / К. Д. Бабов, Е. М. Никипелова, А. В. Мокиенко [и др.] // Екологія довкілля та безпеки життєдіяльності. - 2005. № 2. - С. 52-57.

4. Гігієнічна оцінка мінеральних природних столових вод / А. В. Мокієнко, О. М. Нікіпелова, Л. Б. Солодова [та спраги під час прогулянок, фізичного тренування, спортивних змагань. Під час купівлі фасованої води вирішальним фактором при здійсненні вибору для більшості опитаних $є$ смакові якості води. Все це свідчить про те, що жителі м. Тернополя, вживаючи питну воду в достатній кількості, незважаючи на недостатню якість водогінної води, надають перевагу традиційним джерелам водопостачання, а саме водогонам, колодязям і каптажам.

ін.] // Медицинская реабилитация, курортология, физиотерапия. - 2014. - № 1. - С. 54-57.

5. Мокієнко А. В. Мінеральний склад питних та мінеральних вод як фактор впливу на здоров'я населення (огляд літератури) / А. В. Мокієнко // Вода: гигиена и экология. - 2015. - № 1-2. - С. 173-201.

6. Прокопов В. О. Питна вода України: медико-екологічні та санітарно-гігієнічні аспекти : монографія / В. О. Прокопов ; за ред. А. М. Сердюка. - К. : ВСВ «Медицина», 2016. - 400 с.

7. Прибильський В. Л. Яку воду можна пити? / В. Л. Прибильський, В. В. Остапенко // Харчова і переробна промисловість. - 2004. - № 3. - С. 4-5. 